\section{Reaction of common bean lines to Xanthomonas axonopodis pv. phaseoli and Curtobacterium flaccumfaciens pv. flaccumfaciens}

\section{Tamires Ribeiro ${ }^{1 *}$, Cleber Vinicius Giaretta Azevedo ${ }^{1}$, Jose An- tonio de Fatima Esteves ${ }^{1}$, Sérgio Augusto Morais Carbonell ${ }^{1}$, Margarida Fumiko Ito $^{2}$ and Alisson Fernando Chiorato ${ }^{1}$}

\begin{abstract}
The aim of this study was to evaluate the resistance of 58 common bean lines against common bacterial blight (Xanthomonas axonopodis pv. phaseoli) and bacterial wilt (Curtobacterium flaccumfaciens pv. flaccumfaciens). The experimental design consisted of completely randomized blocks, with four replications per pathogen. The results were subjected to variance analysis by the F test at $1 \%$ probability. Significant differences between the treatments indicated different resistance levels among the lines against both pathogens. According to the Scott-Knott test, six lines were resistant to Xanthomonas axonopodis pv. phaseoli, 14 moderately resistant, and 38 susceptible. To Curtobacterium flaccumfaciens pv. flaccumfaciens, 11 lines were resistant, 26 moderately resistant and 21 susceptible. Among these, the lines Pr10-3-4/1, Pr10-5-2/1 and Pr10-5$2 / 2$ of the black bean group and C10-2-4/2 of the Carioca group were resistant to both major bacterial diseases affecting common bean in Brazil.
\end{abstract}

Key words: Phaseolus vulgaris L., plant breeding, common bacterial blight, bacterial wilt.

\section{INTRODUCTION}

Common bean (Phaseolus vulgaris L.) is a major source of vegetable protein for direct human consumption. In addition, it also contains carbohydrates, dietary fiber, B-complex vitamins, iron, calcium, and other minerals, playing an important role in the diet of the Brazilian population (Vieira et al. 2006).

According to data of CONAB (2015), the mean grain yield in Brazil is about $1.095 \mathrm{~kg} \mathrm{ha}^{-1}$, well below the productive potential of a crop which, under appropriate conditions, can yield more than $4.000 \mathrm{~kg} \mathrm{ha}^{-1}$. This low productivity can be attributed to the incidence of pests and diseases, adverse environmental conditions, low-yielding cultivars, and sowing outside the agricultural zones (Oliveira et al. 2005).

Among the main diseases affecting common bean are common bacterial blight, caused by Xanthomonas axonopodis pv. phaseoli (Smith) Dye and bacterial wilt, caused by Curtobacterium flaccumfaciens pv. flaccumfaciens (Hedges) Collins \& Jones. These pathogens are widespread in the producing regions, causing yield losses, especially when stimulated by favorable environmental conditions such as high temperatures (Theodoro 2004)
Crop Breeding and Applied Biotechnology 17: 40-46, 2017 Brazilian Society of Plant Breeding. Printed in Brazil http://dx.doi.org/10.1590/198470332017v17n1a6 
The first pathogen symptoms of common bacterial blight appear on the shoot, consisting primarily of small watersoaked areas in the leaves, evolving to necrosis and imperfections in the seeds such as discoloration of the hilum, yellow spots, and wrinkling of the seed coat, which can reduce yields by 10 to 70\% (Diaz et al. 2001, Bianchini et al. 2005). The inheritance of resistance to this pathogen is genetically complex, described by several authors as oligogenic or polygenic (Kelly et al. 2003, Santos et al. 2003, Manzanera et al. 2005). According to Zapata et al. (2010), Ferreira and Grattapaglia (2003), and Marquez et al. (2007), the number of genes, degrees and interactions involved in the expression of this trait may vary. Thus, the strong environmental influence in the evaluation period of the genotypes, can explain the low heritability observed in studies focused on the introgression of resistance into segregating common bean populations. Another factor that hampers the development of resistant genotypes for breeding programs is the genetic diversity of the pathogen (Mkandawire et al. 2004).

The pathogen symptoms of bacterial wilt begin with the colonization of vascular tissues, leading to the drying of apical leaflets, yellowing and gradual wilting of leaves, yellowish areas and necrosis of the parenchyma, as well as to yield drop (Maringoni 2002). According to Valentini et al. (2011), the resistance inheritance of this pathogen is polygenic and, according to Souza et al. (2006b), Wendland et al. (2008), and Torres et al. (2009b), the occurrence of genetic diversity and widespread dissemination in the producing regions of Brazil, makes the development of resistance sources even more difficult. For this reason, techniques have been developed to identify this bacterium in common bean crops (Maringoni 2002, Hsieh et al. 2005, Herbes et al. 2008), as well as to evaluate the resistance of genotypes and lines, with a view to the development of new resistant cultivars (Maringoni 2002, Souza et al. 2006a, Theodoro et al. 2007).

Both bacterial diseases are controllable by phytotechnical treatments such as crop rotation, elimination of crop residues and sowing of healthy seeds, whereas the use of resistant cultivars is the most efficient method to minimize production costs, avoiding significant yield and grain quality losses (Hsieh et al. 2005, Souza et al. 2006a, Huang et al. 2007b).

Moderate resistance to common bacterial blight or bacterial wilt was identified in the genotypes IAC Pyatã, IAC Diplomata, CNFC 10408, L 185633, IAPAR 16, UTF 6, PB 4, BRS Campeiro, IPR Chopim, XAN 159, LP 99-79, LP 93-23, L 645132, LP 01-51, PI 2072620, SCS 202-GUARÁ, IAPAR 81, L 264219, lapar 80, LH 11, BRS Radiante, SM 9906, UTF 4, lapar 20, IPR Uirapuru, and IAPAR 3 by Maringoni (2002), Rava et al. (2003), Souza et al. (2006a), Theodoro and Maringoni (2006), Costa et al. (2008), Silva et al. (2009), and Maringoni et al. (2015). These authors emphasized the importance of obtaining resistance sources to both bacterial diseases. Thus, the purpose of this study was to evaluate the resistance reaction of 58 advanced common bean lines to $X$. axonopodis pv. phaseoli and C. flaccumfaciens pv. flaccumfaciens.

\section{MATERIAL AND METHODS}

The experiments were conducted at the Experimental Center of Farm Santa Elisa, Instituto Agronômico-IAC, in

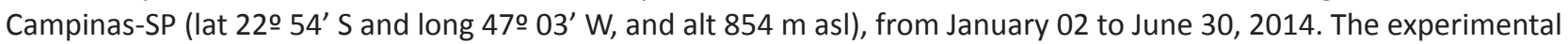
design was arranged in completely randomized blocks, with four replications for each evaluated pathogen. Each repetition consisted of one pot with two plants. Inside the greenhouse, the temperature varied from $28{ }^{\circ} \mathrm{C}$ to $32{ }^{\circ} \mathrm{C}$ during the experimental period.

Fifty-eight advanced common bean lines derived from the following crosses were evaluated: IPR Colibri x P5-4-4-1; Gen C2-1-1 x IAC Alvorada; IAC Alvorada x C6-9-10-1; Gen C4-8-2- 2 x IPR Colibri; LP02-02 x IAC Alvorada; IAC Alvorada $x$ IAC Ybaté; Branquinho x IAC Imperador, Pr15-3-4-1 x Acesso Argentino; Pr15-5-15-1 x LP04-72; IAC Diplomata x LP04-72; IPR - Uirapuru x (IAC Una x XAN 251); IAC Una x LP04-72; P11-5-9-1 x Una IAC; IAC Diplomata x LP04-72; IAC Diplomata $x$ (IAC Una x Acesso Argentino); ( IAC Una x Acesso Argentino) x IAC Diplomata; P5-3-9-2 x IPR Colibri; IPR Colibri x IAC Imperador; LP04-72 x Pr13-3-4-1; (IAC Diplomata x LP04-72) x IAC Una; and P12-1-11-1 x LP04-72.

To evaluate the reactions of the lines to $X$. axonopodis pv. phaseoli (Common bacterial blight), seeds of 58 lines and the susceptible control (Rosinha G2) were disinfected with $70 \%$ ethanol and then with $1.25 \%$ sodium hypochlorite for 5 min. Subsequently, they were spread on paper sheets for germination and placed in BOD at 28 으 for three days. After this period, the seedlings were transplanted into pots containing $500 \mathrm{~g}$ substrate (organic compound and soil, 1:1) and placed in the greenhouse. 
The isolate 11.280 of $X$. axonopodis pv. phaseoli, from the Plant Health Center of the Instituto Agronômico-IAC, Campinas, SP, was used. The isolate was multiplied on PDA (potato, dextrose, agar) and incubated at $28^{\circ} \mathrm{C}$ for 48 hours. Thereafter, inoculum was prepared by addition of distilled water and sterilization in the bacterial colony, scraping with a glass slide, and concentration adjustment to $108 \mathrm{CFU} \mathrm{mL}^{-1}$.

Plants in the $\mathrm{V}_{2}$ stage were inoculated by the technique of multiple needles, according to Pompeu and Crowder (1973). The primary leaves were perforated with light pressure to allow the pathogen to enter the plant. Then the pots were placed in a moist chamber for 48 hours, at temperatures between $25^{\circ} \mathrm{C}$ and $28{ }^{\circ} \mathrm{C}$, and then transferred to the greenhouse.

Ten days after inoculation, the plants were evaluated on a 1 - 9 scale as follows: 1 to 2 - plants free of disease symptoms; 3 to 6 - small water-soaked areas; and 7 to 9 - plant tissue necrosis (Rava and Sartorato (1994). The resistance of genotypes was determined as follows: resistant lines had mean scores between 1 and 2; moderately resistant, between 2.1 and 5; and susceptible, between 5.1 and 9 .

To evaluate reactions to $C$. flaccumfaciens pv. flaccumfaciens, seeds of the 58 lines and the pathogen-susceptible control (Rosinha $\mathrm{G}_{2}$ ) were pre-germinated under laboratory conditions, as described above and transplanted into pots in the greenhouse.

The isolate used in this study was Feij-14627, provided by the Faculdade de Ciências Agronômicas, UNESP, in Botucatu. The isolate was multiplied in NA (Nutrient Sucrose Agar) culture medium and incubated at $28^{\circ} \mathrm{C}$ for 72 hours. Inoculation was carried out in a greenhouse when the plants reached the $V_{3}$ developmental stage, by drilling two holes into the stem between the cotyledons and the primary leaves, using an entomological needle after dipping into the bacterial colony (Maringoni 2002).

Thirty days after inoculation, the plants were evaluated on a 1 - 9 scale adapted by Maringoni (2002) as follows: 0, plants without disease symptoms; 1 - mosaic symptoms on the leaves; 2 - 10\% withered leaves; 5 - 25\% of wilting and yellowing leaves; 7 - 50\% withered leaves, yellowing and necrosis; and 9 - 75\% withered leaves, yellowing and necrosis. The resistant genotypes were determined as follows: resistant lines scored between 1 and 2; moderately resistant, between 2.1 and 5; and susceptible, between 5.1 and 9 .

The experiments were conducted separately. The results were subjected to analysis of variance (ANOVA) using the statistical software Genes (Cruz 2013), and differences between means were compared by the Scott-Knott test at 5\% probability.

\section{RESULTS AND DISCUSSION}

The results of this study show the importance of knowing the resistance reaction of common bean genotypes to common bacterial blight and bacterial wilt. The evaluation of these genotypes is useful in breeding programs, to choose continuous sources of disease resistance, coupled with important agronomic traits, such as early cycle, high yield, upright growth, and resistance to grain darkening, with a view to develop superior genotypes for the productive sector.

The data of the evaluations of the 58 common bean lines regarding resistance to Xanthomonas axonopodis pv. phaseoli and C. flaccumfaciens pv. flaccumfaciens were subjected to analysis of variance by the $\mathrm{F}$ test at $1 \%$ probability. Table 1

Table 1. Summary of analysis of variance of 58 common bean lines inoculated with common bacterial blight (Xanthomonas axonopodis pv. phaseoli) and bacterial wilt (Curtobacterium flaccumfaciens pv. flaccumfaciens)

\begin{tabular}{lccc}
\hline & & \multicolumn{2}{c}{ Mean square } \\
\cline { 3 - 4 } Sources of variation & df & CBB & BW \\
\hline Treatments & 57 & $236.5848^{* *}$ & $0.9849 * *$ \\
Error & 174 & 5.0785 & 0.02369 \\
Total & 231 & & 7.40 \\
\hline CV (\%) & & 13.65 & 2.07 \\
Mean & & 16.50 & \\
\hline
\end{tabular}

** Significant at $1 \%$ probability by the $\mathrm{F}$ test; $\mathrm{CBB}=\mathrm{Common}$ Bacterial Blight and $\mathrm{BW}=$ Bacterial Wilt. 
shows significant differences between treatments, indicating different resistance levels of the common bean lines to the two studied pathogens. The experimental precision, with coefficients of variation of $7.40 \%$ and $13.65 \%$, indicated low environmental influence during the experiments, ensuring reliability of the results.

Differential reactions of the lines to the $X$. axonopodis pv. phaseoli isolate were shown by the Scott-Knott test. Of the 58 lines, 6 were resistant to the pathogen (10\%), 21 moderately resistant (36.20\%), and 31 were susceptible (53.44\%) (Table 2).

The low percentage of resistant genotypes to common bacterial blight can be explained by the occurrence of additive and non-additive effects, resulting in complex inheritance, as reported by Marquez et al. (2007). Six QTLs in $F_{3}$ plants resulting from the BAC- 6 and HAB-52 cross were identified by Santos et al. (2003). Five of these QTLs were associated with resistance of leaves and one of pods, with a phenotypic variation from 12.7 to $68.7 \%$ for leaf and $12.9 \%$ for pod resistance. These results highlight the complexity of the trait, where the genes that control leaf resistance are not the same as those that control pod resistance, indicating the occurrence of oligo- or polygenic interaction, reinforcing the complex nature of resistance to the pathogen.

Among 56 evaluated cultivars, Silva (2009) identified 21 as resistant to common bacterial blight and among 61

Table 2. Resistance of 58 common bean lines to common bacterial blight (Xanthomonas axonopodis pv. phaseoli) and bacterial wilt (Curtobacterium flaccumfaciens pv. flaccumfaciens)

\begin{tabular}{|c|c|c|c|c|c|}
\hline \multirow[b]{2}{*}{ Line } & \multicolumn{2}{|c|}{ Mean } & \multirow[b]{2}{*}{ Line } & \multicolumn{2}{|c|}{ Mean } \\
\hline & $\begin{array}{c}\text { Common } \\
\text { Bacterial Blight }\end{array}$ & $\begin{array}{c}\text { Bacterial } \\
\text { Wilt }\end{array}$ & & $\begin{array}{c}\text { Common } \\
\text { Bacterial Blight }\end{array}$ & $\begin{array}{l}\text { Bacterial } \\
\text { Wilt }\end{array}$ \\
\hline 1. $\operatorname{Pr} 10-4-4 / 11$ & $1.00 \mathrm{aR}$ & $3.50 \mathrm{bMR}$ & 30. C10-2-4/36 & $7.00 \mathrm{fS}$ & $5.00 \mathrm{dMR}$ \\
\hline 3. $\operatorname{Pr} 10-5-2 / 2$ & $1.00 \mathrm{aR}$ & $1.50 \mathrm{aR}$ & 32. $\mathrm{P} 10-1-2 / 13$ & $7.00 \mathrm{fS}$ & $3.25 \mathrm{bMR}$ \\
\hline 4. $C 10-2-4 / 2$ & $2.00 \mathrm{bR}$ & $1.00 \mathrm{aR}$ & 33. $\operatorname{Pr} 10-4-3 / 13$ & $7.00 \mathrm{fS}$ & $4.50 \mathrm{cMR}$ \\
\hline 7. C10-2-4/57 & $3.75 \mathrm{cMR}$ & $2.00 \mathrm{aR}$ & 36. P10-1-3/1 & $7.50 \mathrm{fS}$ & $6.00 \mathrm{eS}$ \\
\hline 8. $P 10-1-3 / 16$ & $3.75 \mathrm{cMR}$ & $5.50 \mathrm{eS}$ & 37. $P 10-1-4 / 2$ & $7.50 \mathrm{fS}$ & $7.00 \mathrm{fS}$ \\
\hline 9. P10-1-1/12 & $4.50 \mathrm{dMR}$ & $2.00 \mathrm{aR}$ & 38. $\operatorname{Pr} 10-5-1 / 14$ & $7.50 \mathrm{fS}$ & $3.75 \mathrm{cMR}$ \\
\hline 10. P10-1-9/38 & $4.50 \mathrm{dMR}$ & $2.00 \mathrm{aR}$ & 39. $\operatorname{Pr} 10-5-1 / 2$ & $7.50 \mathrm{fS}$ & $3.00 \mathrm{bMR}$ \\
\hline 11. $\operatorname{Pr} 10-8-3 / 2$ & $4.50 \mathrm{dMR}$ & $7.50 \mathrm{fS}$ & 40. $\operatorname{Pr} 10-5-2 / 4$ & $7.50 \mathrm{fS}$ & $7.00 \mathrm{fS}$ \\
\hline 15. C10-2-4/35 & $5.00 \mathrm{dMR}$ & $2.00 \mathrm{aR}$ & 44. P10-1-1/19 & $8.00 \mathrm{gS}$ & $4.50 \mathrm{cMR}$ \\
\hline 16. $\mathrm{C} 10-2-4 / 41$ & $5.00 \mathrm{dMR}$ & $6.50 \mathrm{eS}$ & 45. $\operatorname{Pr} 10-3-4 / 2$ & $8.00 \mathrm{gS}$ & $6.00 \mathrm{eS}$ \\
\hline 17. P10-1-4/23 & $5.00 \mathrm{dMR}$ & $5.00 \mathrm{dMR}$ & 46. $\operatorname{Pr} 10-4-4 / 27$ & $8.00 \mathrm{gS}$ & $3.00 \mathrm{bMR}$ \\
\hline 18. $\operatorname{Pr} 10-4-2 / 10$ & $5.00 \mathrm{dMR}$ & $3.50 \mathrm{bMR}$ & 47. C10-2-17/4 & $8.50 \mathrm{gS}$ & $5.50 \mathrm{eS}$ \\
\hline 19. $\operatorname{Pr} 10-5-2 / 3$ & $5.00 \mathrm{dMR}$ & $2.00 \mathrm{aR}$ & 48. $\operatorname{Pr} 10-3-2 / 35$ & $8.50 \mathrm{gS}$ & $8.50 \mathrm{gS}$ \\
\hline 20. $\operatorname{Pr} 10-7-1 / 6$ & $5.00 \mathrm{dMR}$ & $8.50 \mathrm{gS}$ & 49. $\operatorname{Pr} 10-4-3 / 14$ & $8.50 \mathrm{gS}$ & $5.00 \mathrm{dMR}$ \\
\hline 21. $\operatorname{Pr} 10-3-3 / 8$ & $5.25 \mathrm{eS}$ & $3.25 \mathrm{bMR}$ & 50. $\operatorname{Pr} 10-7-1 / 16$ & $8.50 \mathrm{gS}$ & $5.50 \mathrm{eS}$ \\
\hline 22. C10-2-16/8 & $6.00 \mathrm{eS}$ & $3.25 \mathrm{bMR}$ & 51. C10-2-16/7 & $9.00 \mathrm{hS}$ & $6.50 \mathrm{eS}$ \\
\hline 23. C10-2-17/3 & $6.00 \mathrm{eS}$ & $2.00 \mathrm{aR}$ & 52. P10-1-3/17 & $9.00 \mathrm{hS}$ & $4.00 \mathrm{cMR}$ \\
\hline 24. $\mathrm{C} 10-2-4 / 12$ & $6.00 \mathrm{eS}$ & $5.50 \mathrm{eS}$ & 53. $\operatorname{Pr} 10-3-3 / 9$ & $9.00 \mathrm{hS}$ & $4.00 \mathrm{cMR}$ \\
\hline
\end{tabular}

Means values followed by different lowercase letters are significantly different between lines by the Scott-Knott test, at $5 \%$ probability and different uppercase letters indicate reactions of the lines to the common bacterial blight and bacterial wilt isolates ( $\mathrm{R}=$ resistant: scores between 1.00 and 2.00 ; $\mathrm{MR}=$ moderately resistant: scores between 2.10 and $6,00 \mathrm{~S}=$ susceptible: scores between 6.10 and 9.00 ). 
genotypes, Costa et al. (2008) identified the cultivars Magnifico, Radiante and BRS Pontal as resistant. In our study, six lines were selected, one of which belongs to the Carioca group (C10-2-4/2) and five to the black bean group ( $\operatorname{Pr} 10-4-$ 4/11, $\operatorname{Pr} 10-5-2 / 1, \operatorname{Pr} 10-5-2 / 2, \operatorname{Pr} 10-3-4 / 1$ and $\operatorname{Pr} 10-3-5 / 10)$. These six resulted from the respective crosses: IAC Alvorada x C6-9-10-1; IAC Una x LP04-72; IPR-Uirapuru x (IAC Una x XAN 251); IPR-Uirapuru x (IAC Una x XAN 251); (IAC Diplomata $x$ LP04 -72) x IAC Una and (IAC Una x Acesso Argentino) x IAC Diplomata (Table 3).

The resistant lines of the black bean group (Pr10-4-4/11, Pr10-5-2/1, Pr10-5-2/2, Pr10-3-4/1 and Pr10-3-5/10), were derived from the parents IPR-Uirapuru, IAC Una or IAC Diplomata. The former two were classified, respectively, as resistant and moderately resistant by Silva et al. (2009), while IAC Diplomata was classified as susceptible by Azevedo et al. (2015). The resistant line of the Carioca group C10-2-4/2 was derived from the parent IAC Alvorada, classified as susceptible to common bacterial blight by Azevedo et al. (2015).

The difficulty in the development of resistant genotypes motivated several authors to approach this problem by identifying bacteria in seeds. However, Denardin and Agostini (2013) and Silva et al. (2013) described the complexity of pathogen identification on seeds and highlighted the importance of finding resistance sources, due to the wide dissemination of the pathogen in the producing areas of common bean.

The Scott-Knott test showed a differential reactions among the lines to $C$. flaccumfaciens pv. flaccumfaciens. Among the 58 lines, 11 were resistant to the pathogen (18.96\%), 26 moderately resistant (44.82\%) and 21 were susceptible (36.20\%) (Table 2).

Of 333 tested genotypes, Souza et al. (2006a) found $18 \%$ to be resistant, which is consistent with our results. The low percentage of genotypes resistant to bacterial wilt was mentioned by Theodoro and Maringoni (2006). These authors evaluated 73 lines and found only two resistant cultivars (Mouro Piratuba and Vagem Amarela). According to Valentini et al. (2011), the low rate of resistant genotypes can be explained by the occurrence of additive and non-additive effects in the inheritance of bacterial wilt resistance. These authors identified more than three resistance genes in two populations resulting from the crosses IAC Carioca Aruã x SCS Guará and IAC Carioca Pyatã x Perola.

In this study, 11 lines were classified as bacterial wilt resistant, 7 of which belong to the Carioca group (C10-2-4/2, C10-2-4/57, P10-1-1/12, P10-1-9/38, C10-2-4/35, C10-2-17/3, and P10-1-9/39) and 4 to the black bean group (Pr10-5-2/1,

Table 3. Common bean lines and their respective original crosses resistant to common bacterial blight (Xanthomonas axonopodis pv. phaseoli) and bacterial wilt (Curtobacterium flaccumfaciens pv. flaccumfaciens)

\begin{tabular}{|c|c|c|}
\hline \multicolumn{3}{|c|}{ Common bacterial blight } \\
\hline Line & Cross & Market class \\
\hline 1. $C 10-2-4 / 2$ & IAC Alvorada x C6-9-10-1 & Carioca \\
\hline 2. $\operatorname{Pr} 10-3-5 / 10$ & (IAC Una x Acesso Argentino) $\times$ IAC Diplomata & Black \\
\hline 3. $\operatorname{Pr} 10-3-4 / 1$ & (IAC Diplomata x LP04-72) x IAC Una & Black \\
\hline 4. $\operatorname{Pr} 10-5-2 / 1$ & IPR - Uirapuru x (IAC Una x XAN 251) & Black \\
\hline 5. $\operatorname{Pr} 10-5-2 / 2$ & IPR - Uirapuru x (IAC Una x XAN 251) & Black \\
\hline Line & Cross & Market class \\
\hline 1. $C 10-2-4 / 2$ & IAC Alvorada x C6-9-10-1 & Carioca \\
\hline 2. $\mathrm{C} 10-2-4 / 57$ & IAC Alvorada x C6-9-10-1 & Carioca \\
\hline 3. $\mathrm{P} 10-1-1 / 12$ & IPR Colibri x P5-4-4-1 & Carioca \\
\hline 4. $P 10-1-9 / 38$ & P5-3-9-2 x IPR Colibri & Carioca \\
\hline 8. $\operatorname{Pr} 10-5-2 / 1$ & IPR - Uirapuru x (IAC Una x XAN 251) & Black \\
\hline 9. $\operatorname{Pr} 10-5-2 / 2$ & IPR - Uirapuru x (IAC Una x XAN 251) & Black \\
\hline 10. $\operatorname{Pr} 10-3-4 / 1$ & (IAC Diplomata x LP04-72) x IAC Una & Black \\
\hline 11. $\operatorname{Pr} 10-5-2 / 3$ & (IAC Diplomata x LP04-72) x IAC Una & Black \\
\hline
\end{tabular}


$\operatorname{Pr} 10-5-2 / 2, \operatorname{Pr} 10-3-4 / 1$, and $\operatorname{Pr} 10-5-2 / 3)$, resulting from the respective crosses IAC Alvorada x C6-9-10-1, IAC Alvorada $x$ C6-9-10-1, IPR Colibri x P5-4-4-1, P5-3-9-2 x IPR Colibri, IAC Alvorada x C6-9-10-1, Gen C2-1-1 x IAC Alvorada, P5-3-9-2 x IPR Colibri, IPR-Uirapuru x (IAC Una x XAN 251), IPR-Uirapuru x (IAC Una x XAN 251), (IAC Diplomata x LP04-72) x IAC Una, and (IAC Diplomata x LP04-72) x IAC Una (Table 3).

Of these 11 lines, C10-2-4/57, Pr10-3-4/1, Pr10-5-2/1, Pr10-5-2/2, C10-2-4/2, C10 2-17/3, and C10-2-4/35 were originated from the parents IAC Diplomata, IAC Alvorada, IAC Una, or IPR-Uirapuru. IAC Diplomata and IAC Alvorada were classified as resistant, while IAC Una was classified as susceptible by Maringoni et al. (2015). Parent IPR-Uirapuru was classified as susceptible to C. flaccumfaciens pv. flaccumfaciens by Theodoro et al. (2007) and Maringoni et al. (2015).

According to Souza and Maringoni (2008), resistant genotypes involve the pathogen by protoplasmic projections, preventing its installation in the xylem vessels, while in susceptible genotypes the water transport is obstructed by the presence of bacterial cells. These results are related to the disease symptoms, e.g., plant wilting, yellowing, underdevelopment, and death, observed at different levels of aggressiveness in the 58 lines evaluated in this study.

The lines C10-2-4/2, Pr10-3-4/1, Pr10-5-2/1, and Pr10-5-2/2 (Table 3) were resistant to common bacterial blight and bacterial wilt, the two major bacterial diseases affecting common bean in Brazil. The development of these cultivars is extremely important to maintain the yield and grain quality of common bean, given the lack of resistant cultivars in the productive sector, the physiological variability and wide dissemination of the pathogens in crop areas.

\section{ACKNOWLEDGEMENTS}

The authors thank the Fundação de Pesquisa do Estado de São Paulo (FAPESP) for the financial support.

\section{REFERENCES}

Azevedo CVG, Ribeiro T, Silva DA, Carbonell SAM and Chiorato AF (2015) Adaptabilidade, estabilidade e resistência a patógenos em genótipos de feijoeiro. Pesquisa Agropecuária Brasileira 50: 912-922.

Bianchini A, Maringoni AC and Carneiro SMPG (2005) Doenças do feijoeiro (Phaseolus vulgaris L.). In Kimati H, Amorim L, Rezende JAM, Bergamin Filho $A$ and Camargo LEA. Manual de fitopatologia. $2^{\text {nd }}$ edn, Editora Ceres, São Paulo, 333-349.

CONAB - Companhia Nacional de Abastecimento (2015) Available at <http://www.conab.gov.br/OlalaCMS/uploads/ arquivos/15_12_11_11_02_58_boletim_graos_dezembro_2015. pdf>. Accessed on 25 Dec, 2015.

Costa JGC, Rava CA, Puríssimo JD, Peloso MJD, Melo LC and Faria LC (2008) Reação de genótipos de feijoeiro comum ao crestamento bacteriano comum e à murcha de curtobacterium. Revista Ceres 55: 93-395.

Cruz CD (2013) GENES - a software package for analysis in experimental statistics and quantitative genetics. Acta Scientiarum Agronomy 35: 271-276.

Denardin ND'A and Agostini VA (2013) Detection and quantification of Xanthomonas axonopodis pv. phaseoli and its variant fuscans in common bean seeds. Journal of Seed Science 35: 428-434.

Diaz CG, Bassanezi RB, Godoy CV, Lopes DB and Bergamin Filho A (2001) Quantificação do efeito do crestamento bacteriano comum na eficiência fotossintética e na produção do feijoeiro. Fitopatologia Brasileira 26: 71-76.

Ferreira ME and Grattapaglia D (2003) Introdução ao uso de marcadores moleculares em análise genética. Embrapa-Cenargen 3: 220.
Herbes DH, Theodoro GF, Maringoni AC, Dal Piva CA and Abreu L (2008) Deteç̧ão de Curtobacterium flaccumfaciens pv. flaccumfaciens em sementes de feijoeiro produzidas em Santa Catarina. Tropical Plant Pathology 33: 53-156.

Hsieh TF, Huang HC, Mündel HH, Conner RL, Erickson RS and Balasubramanian PM (2005) Resistence of common bean (Phaseolus vulgaris) to bacterial wilt caused by Curtobacterium flaccumfaciens pv. flaccumfaciens. Phytopathology 153: 245-249.

Huang HC, Erickson RS and Hsieh TF (2007b) Control of bacterial wilt of bean (Curtobacterium flaccumfaciens pv. flaccumfaciens) by seed treatment with Rhizobium leguminosarum. Crop Protection 26: 1055-1061.

Kelly JD, Gepts P, Miklas PN and Coyne DP (2003) Tagging and mapping of genes and QTL and molecular marker-assisted selection for traits of economic importance in bean and cowpea. Field Crops Research 82: $135-154$

Manzanera MAS, Asensio C and Singh SP (2005) Gamete selection for resistance to common and halo bacterial blights in dry bean intergene pool populations. Crop Science 46: 131-135.

Maringoni AC (2002) Comportamento de cultivares de feijoeiro comum à murcha-de- curtobacterium. Fitopatologia Brasileira 27: 157-166.

Maringoni AC, Ishiszuka MS, Silva AP, Soman JM, Moura MF, Santos RL, Júnior TAFS, Chiorato AF, Carbonell SAM and Júnior NSF (2015) Reaction and colonization of common bean genotypes by Curtobacterium flaccumfaciens pv. flaccumfaciens. Crop Breeding and Applied Biotechnology 15: 87-93.

Marquez ML, Terán H and Singh SP (2007) Selecting common bean with genes of different evolutionary origins 


\section{T Ribeiro et al.}

for resistance to Xanthomonas campestris pv. phaseoli. Crop Science 47: 1367-1374.

Mkandawire ABC, Mabagala RB, Guzman P, Gepts P and Gilbertson RL (2004) Genetic and Pathogenic variation of common blight bacteria (Xanthomonas axonopodis pv. phaseoli and X. axonopodis pv. phaseoli var. fuscans). Phytopathology 94: 593-603.

Oliveira AD, Fernandes EJ and Rodrigues TJD (2005) Condutância estomática como indicador de estresse hídrico em feijão. Engenharia Agrícola 25: 86-95.

Pompeu AS and Crowder LV (1973) Métodos de inoculação e concentrações bacterianas de Xanthomonas phaseoli, para a herança da reação a doença em Phaseolus vulgaris sob condições de câmara de crescimento. Ciência e Cultura 25: 1078-1081.

Rava CA and Sartorato A (1994) Crestamento bacteriano comum. Principais doenças do feijoeiro comum e seu controle. Embrapa, Brasília (CNPAF 300).

Rava CA, Costa JGC, Fonseca JR and Salgado AL (2003) Fontes de resistência à antracnose, crestamento-bacteriano-comum e murchade-curtobacterium em coletas de feijoeiro comum. Revista Ceres 50: 797-802.

Santos AS, Bressan-Smith RE, Pereira MG, Rodrigues R and Ferreira CF (2003) Genetic Linkage Map of Phaseolus vulgaris L. and identification of QTLs responsible for resistance to Xanthomonas axonopodis pv. phaseoli. Fitopatologia Brasileira 28: 5-10.

Silva A, Santos I, Balbinot AL, Matei G and Oliveira PH (2009) Reação de genótipos de feijão ao crestamento bacteriano comum, avaliado por dois métodos de inoculação. Ciência Agrotécnica 33: 2019-2024.

Silva FC, Souza RM, Zacaroni AB, Lelis FMV and Figueira AR (2013) Otimização da técnica de PCR para a detecção de Xanthomonas axonopodis pv. phaseoli em sementes de feijão. Summa Phytopathologica 39: 45-50.

Souza VL and Maringoni AC (2008) Análise ultraestrutural da interação de Curtobacterium flaccumfaciens pv. flaccumfaciens em genótipos de feijoeiro. Summa Phytopathologica 34: 318-320.
Souza VL, Maringoni AC and Krause-Sakate R (2006b) Variabilidade genética em isolados de Curtobacterium flaccumfaciens. Summa Phytopathologica 32: 170-176.

Souza VL, Maringoni AC, Carbonell SAM and Ito MF (2006a) Resistência genética em genótipos de feijoeiro a Curtobacterium flaccumfaciens pv. flaccumfaciens. Summa Phytopathologica 32: 339-344.

Theodoro GF (2004) Reação de cultivares locais de feijão a Xanthomonas axonopodis pv. phaseoli, em condições de campo. Revista Brasileira Agrociência 10: 373-375.

Theodoro GF and Maringoni AC (2006) Effect of potassium levels in the severity of bacterial wilt in common bean cultivars. Summa Phytopathologica 32: 139-146.

Theodoro GF, Herbes DH and Maringoni AC (2007) Fontes de resistência à murcha-de-curtobacterium em cultivares locais de feijoeiro, coletadas em Santa Catarina. Ciência e Agrotecnologia 31: 333-339.

Torres JP, Silva Júnior TAF and Maringoni AC (2009b) Detecção de Xanthomonas axonopodis pv. phaseoli em sementes de feijoeiro provenientes do Estado do Paraná, Brasil. Summa Phytopathologica 35: 136-139.

Valentini G, Baldissera JNC, Morais PPP, Stähelin D, Heidemann JC, Stenger F, Elias HT, Guidolin AF and Coimbra JLM (2011) Herança da resistência em feijão à murcha causada por Curtobacterium flaccumfaciens pv. flaccumfaciens. Pesquisa Agropecuária Brasileira 46: 1045-1052.

Vieira C, Paula Júnior TJ and Borém A (2006) Feijão. Editora UFV, Viçosa, 600 .

Wendland A, Alencar NA, Melo LC, Costa JGC, Del Peloso MJ, Pereira HS, Faria LC, Côrtes MVCB and Brondani RPV (2008) Padrão de sintomas de isolados de Curtobacterium flaccumfaciens pv. flaccumfaciens em dois genótipos de feijoeiro. Boletim de Pesquisa e Desenvolvimento Embrapa Arroz e Feijão 33: 19.

Zapata M, Beaver JS and Porch TG (2010) Dominant gene for common bean resistance to common bacterial blight caused by Xanthomonas axonopodis pv. phaseoli. Euphytica 179: 373-382. 